\title{
TREATING LEATHER SHAVING WASTE TO DECREASE ITS ENVIRONMENTAL IMPACT
}

\author{
Taha, Mohamed G. ${ }^{1}$, Ahmed I. Nasr ${ }^{2 *}$, Hamdy E. Ali ${ }^{1}$ and \\ Mahmoud A. Essa ${ }^{2}$ \\ ${ }^{1}$ Department of Biochemistry, Faculty of Agriculture, Al-Azhar \\ University, Cairo, Egypt \\ ${ }^{2}$ Department of Wool Production and Technology, Desert Research \\ Center, El Matareya, Cairo, Egypt \\ *E-mail: ainasr@yahoo.com
}

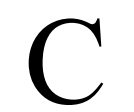

hrome shaving waste (CSW) is one of the largest leather tanning wastes, caused an economical and environmental loss if it did not utilize properly. This study aims to extract chromium from chrome shaving waste, by alkaline hydrolysis or incineration in order to reuse it in leather tanning. Sodium hydroxide and carbonate were used in chemical hydrolysis and compared with incineration method in chrome yielding. Twenty five sheep pelts were tanned with recovered and commercial chromium 33\% basicity to compare their effects in tanning. The results showed that among alkaline treatments, caustic soda was more effective than sodium carbonate in extraction, but incineration method was the best extraction method because of its high extraction yield $(99.37 \%)$. Using sugar as a reducing agent was better than sodium sulphite to prepare tanning liquor. It increased chrome yield and produced chromium sulphate $33 \%$ basicity, which are more suitable for leather tanning. Most physical and chemical properties, except fat and ash contents, were similar in leathers tanned with recovered chrome and those tanned with commercial chrome. Thus, all studied tanned leathers were suitable for using in leather manufacturing.

Keywords: chrome, physical properties, recovery, tanning

Leather tanning process transforms raw hides or skins into leatherfinal product. Chrome tanning is the most widely leather tanning method used in the world. Liquid and solid pollution loads at various processing stages were generated in leather tanning (Beltrán-Prieto et al., 2012). Each one metric ton of raw hide provides $200 \mathrm{~kg}$ of a leather-final product, along with $250 \mathrm{~kg}$ of non-tanned waste, $200 \mathrm{~kg}$ of tanned waste and $50,000 \mathrm{~kg}$ of wastewater. Thus, only $20 \%$ of the raw material weight is converted into leather (Sanjuán-Herráez et al., 2012). 
Chrome shaving waste (CSW) is one of the largest solid tanned wastes, generates after mechanical shaving step (Putshaka et al., 2015). Shaving waste primarily consists of chromium and fiber proteins. Due to the complexation among chromium (III) salts and the carboxyl groups of the collagen, shaving waste is stable biologically and not subject to putrefaction (Lakrafli et al., 2012). In Egypt, shaving waste estimated about 30 thousand tons annually (FAOSTAT, 2014), disposes by deep burial, which does not utilize and causes an economic loss.

On the other hand, $\mathrm{Cr}$ (III) in shaving waste can be oxidized into $\mathrm{Cr}$ (VI) under the most oxidation states in the natural environment. Cr (VI) is recognized to be highly toxic and carcinogenic, and thus it causes a negative environmental impact (Sutyasmi and Supraptiningsih, 2014).

All previous investigations aimed to valorize shaving waste by transform it to eco-friendly materials, can be used in other useful proposes. Therefore, the only way to achieve this target is separating chromium salts from shaving wastes and reuses both of obtained free chromium protein and extracted chromium again. Usually extracted chromium salts are reusing in leather tanning, while free chromium protein is used in different purposes such as animal feeding, gelatin industry or amino acids and peptides production (Muralidhara et al., 1982; Alves Dos Reis and Beleza, 1991 and Mohamed et al., 2013).

In literature, incineration and chemical treatments are the most common methods for CSW treatment. Incineration has been considered as a means for reducing waste volume and provide energy recovery from the combustion of the organic material, while chemical treatment includes extraction of chromium to be reused in the tanning process and isolation of protein fractions (Kantarli and Yanik, 2010; Beltrán-Prieto et al., 2012 and Putshaka et al., 2015). Alkaline such as caustic soda or sodium carbonate are usually more effective than acids in chemical hydrolysis for CSW (Mohamed et al., 2013 and Sutyasmi and Supraptiningsih, 2014).

Therefore, the main objective of this study is to extract chromium from CSW by alkaline hydrolysis or incineration to reuse it in leather tanning as well as comparing among these extraction methods in order to pick up the most suitable one.

\section{MATERIALS AND METHODS}

The experimental work was carried out in the Desert Research Center, Cairo, Egypt. Three consecutive stages were done in this work. The first stage is to determine the best chrome recovery method from chrome shaving wastes in order to obtain the highest extraction yield. In the second stage, different chrome extraction conditions were applied to maximize the quantity of recovered chrome. In the last stage, prepared basic chromium 
sulphate (BCS) was used in leather tanning to investigate leather properties were determined.

The chrome shaving wastes used in this study were collected from commercial tannery, located in Cairo, Egypt. After that, it was dried for five days in an open shaded place without using any thermal drying treatment. Characterization of CSW was determined. Moisture, ash, fat, protein, chrome contents, total energy and $\mathrm{pH}$ values of CSW were determined according to ASTM (2014).

\section{Determination of the Best Chrome Recovery Method}

Fig. (1) shows the working steps of this stage, which aimed to compare between alkaline hydrolysis vs. incineration extraction method. Thus, chrome was extracted directly from CSW by alkaline hydrolysis or from chrome shaving ash (CSA) after incineration.

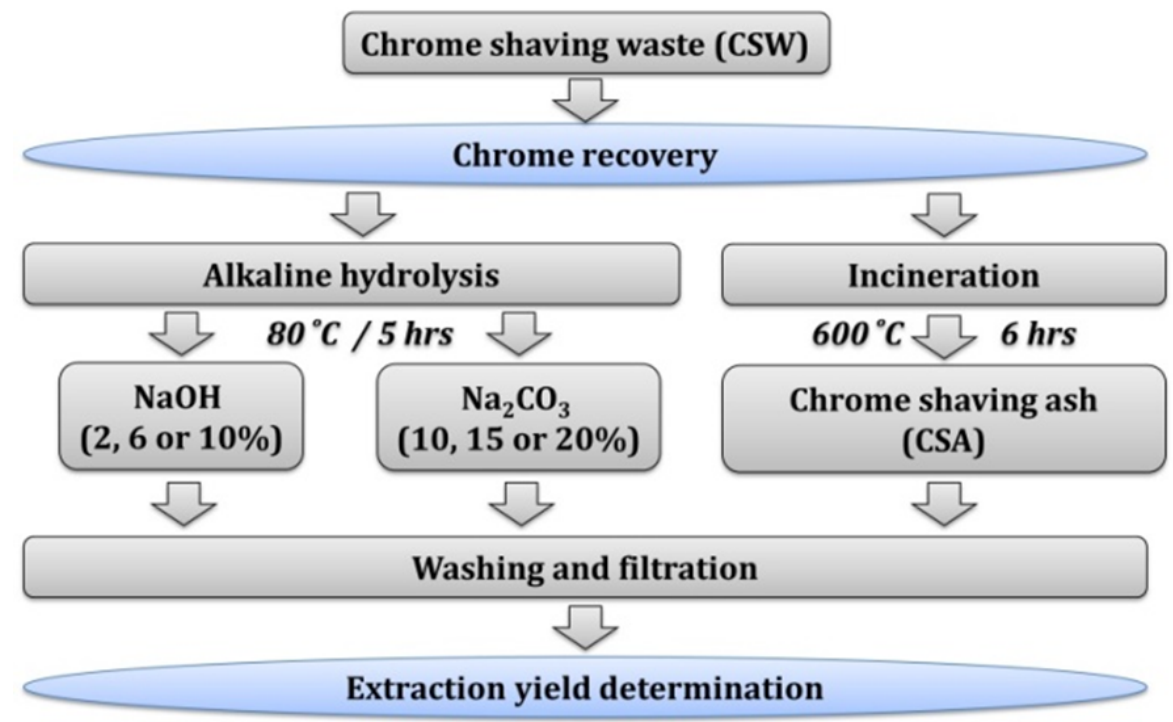

Fig. (1). Schematic diagram for the work plan executed in the first stage of experimental work.

\subsection{Chrome shaving waste incineration}

Ten grams of CSW were incinerated in muffle furnace at $600 \pm$ $25^{\circ} \mathrm{C}$ for 6 hours. After incineration, CSA was washed and filtered through No. 11 Whatman filter paper to dissolve chromium salts and separate it from other residues. 


\subsection{Alkaline hydrolysis of CSW}

Alkaline hydrolysis was done using sodium hydroxide or sodium carbonate, which added as a percentage from CSW weight. Sodium hydroxide was added in three concentrations 2,6 or $10 \%$, while sodium carbonate concentrations were 10,15 and $20 \%$. In each concentration, $10 \mathrm{~g}$ of CSW were placed in $100 \mathrm{ml}$ of distilled water and then chemical additive was added. The mixture was rotated mechanically at $80 \pm 2{ }^{\circ} \mathrm{C}$ for 5 hours. Dissolved chromium salts were filtered and sludge was washed after separation.

\subsection{Extraction yield}

Extraction yield was calculated for each extraction group according to following equation:

Extraction yield $(\%)=\frac{\text { weight of chromium salt in extract }(g)}{\text { weigth of chromium salt in } \operatorname{CSW}(\mathrm{g})} \times 100$

\section{Maximizing the Quantity of Recovered Chrome}

Fig. (2) shows the working steps of this stage. The best extraction method from first stage, incineration method, was repeated under different conditions to increase the quantity of recovered chrome. CSA was dissolved in water and then filtered through No. 11 Whatman filter paper. According to Beltrán-Prieto et al. (2012), the recovered chromium was acidified with sulfuric acid then treated with sodium sulphite or sugar in order to obtain BCS solution, which can be used for leather tanning. During the reaction, the color of the liquor changed gradually from orange to green and finally to bluish green indicating the completion of the reduction (Fig. 3). At the end of this stage, extraction yield and chrome basicity of prepared BCS were determined for each extracted group.

2.1. Preparing basic chromium sulphate using sulphuric acid and sodium sulphite

Three treatments were used at three levels of $\mathrm{pH}$. In each treatment, $1 \mathrm{~g}$ of CSA was placed in flask and $20 \mathrm{ml}$ of distilled water were added, then sulphuric acid solution was used for adjusting $\mathrm{pH}$ values to be $1.00,1.25$ or 1.5. One gram of sodium sulphite was added for reduction and preparing BCS.

2.2. Preparing basic chromium sulphate using sulphuric acid and sugar

According to Salma et al. (2013), $250 \mathrm{~g}$ of CSA were mixed with $625 \mathrm{ml}$ water in a beaker; $230 \mathrm{~g}$ of concentrated sulphuric acid (Sp. Gr. 1.84) were added carefully and stirred well. The beaker was under cooling with continuous stirring, while $62.5 \mathrm{~g}$ of sugar were added slowly in 10 lots over three hours.

Egyptian J. Desert Res., 68, No. 1, 75-88 (2018) 


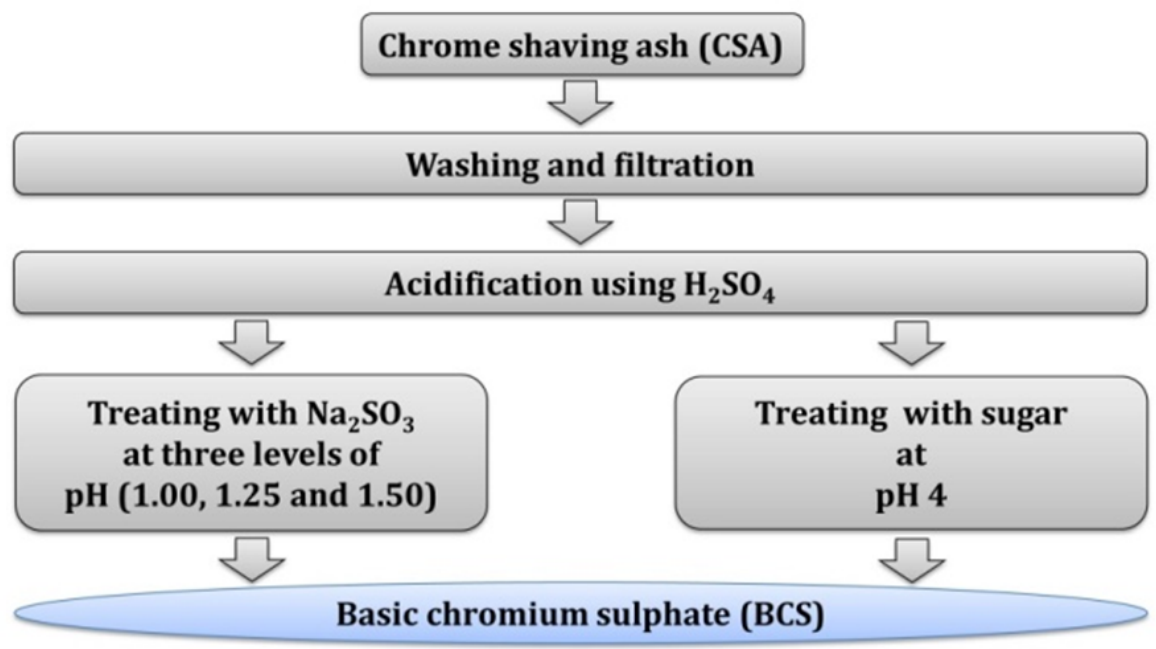

Fig. (2). Schematic diagram for the work plan executed in the second stage of experimental work.

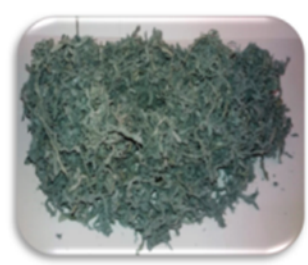

Chrome Shaving Waste (CSW)
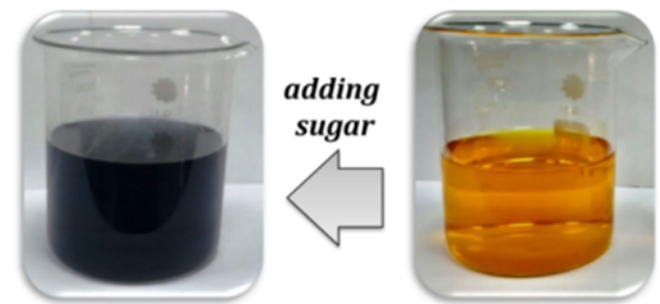

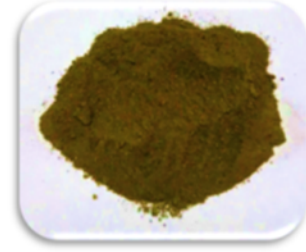

Chrome Shaving Ash (CSA)

Acidification

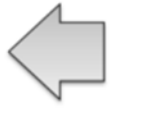

washing

and

filtration
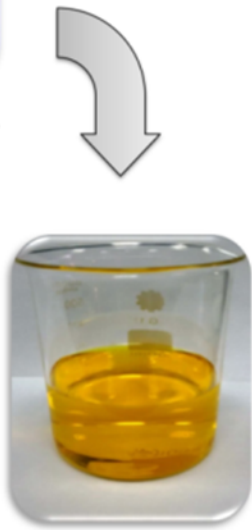

Basic Cr (III) Sulphate (BCS)

Fig. (3). Producing basic chromium sulphate from shaving wastes. 


\section{Using of Prepared Basic Chromium Sulphate in Leather Tanning}

The prepared BCS was used in tanning pickled sheep skins. Twenty five pickled sheep pelts were tanned in El-Shaar tannery with $8 \%$ from pelts' weight of chromium sulphate basicity 33\%. Pickled pelts were divided into five groups, five pelts in each group, which differed in the added amounts of commercial and recovered chrome as follows:

- G1: tanned with $100 \%$ commercial chromium sulphate and $0 \%$ recovered chrome.

- G2: tanned with $75 \%$ commercial chromium sulphate and $25 \%$ recovered chrome.

- G3: tanned with 50\% commercial chromium sulphate and 50\% recovered chrome.

- G4: tanned with $25 \%$ commercial chromium sulphate and $75 \%$ recovered chrome.

- G5: tanned with $0 \%$ commercial chromium sulphate and $100 \%$ recovered chrome.

Tanning and post-tanning steps were done at all tanned leathers according to the recipe in table (1). Qualitative and operational properties of the obtained leathers were assessed according to indices of chemical analysis, physico-mechanical analysis of the finished leather. Thickness, tensile strength, elongation, split tear strength, water absorption, permeability to water vapor, $\mathrm{pH}$, and contents of ash, chrome and moisture were analyzed according to ASTM (2014).

Table (1). Tanning and post tanning steps recipe.

\begin{tabular}{|c|c|c|c|c|}
\hline \multirow{2}{*}{ Step } & \multicolumn{2}{|r|}{ Description } & \multirow{2}{*}{$\begin{array}{l}\text { Time } \\
(\min )\end{array}$} & \multirow{2}{*}{ Notes } \\
\hline & $\% *$ & Added & & \\
\hline Tanning & 8.0 & Chromium sulphate & 90 & Chrome $33 \%$ basicity \\
\hline Fixation & 1.0 & $\begin{array}{c}\text { Sodium } \\
\text { bicarbonate }\end{array}$ & 60 & Overnight, $\mathrm{pH}=3.8-4.2$ \\
\hline Washing & $\begin{array}{c}100.0 \\
2.0 \\
\end{array}$ & $\begin{array}{l}\text { Water } \\
\text { Soap }\end{array}$ & 60 & Drain float \\
\hline Naturalization & $\begin{array}{c}100.0 \\
2.0\end{array}$ & $\begin{array}{c}\text { Water } \\
\text { Sodium } \\
\text { bicarbonate }\end{array}$ & 60 & $\begin{array}{l}\mathrm{pH}=5.5 \\
\text { Drain float }\end{array}$ \\
\hline $\begin{array}{l}\text { Dyeing } \\
\text { and } \\
\text { fatliquoring }\end{array}$ & $\begin{array}{c}150.0 \\
3.0 \\
6.0 \\
\end{array}$ & $\begin{array}{c}\text { Water } \\
\text { Black dye } \\
\text { Fish oil } \\
\end{array}$ & 90 & Bath temperature $40^{\circ} \mathrm{C}$ \\
\hline Fixation & $\begin{array}{l}0.5 \\
0.5\end{array}$ & $\begin{array}{l}\text { Formic acid } \\
\text { Formic acid }\end{array}$ & $\begin{array}{l}30 \\
30\end{array}$ & Overnight \\
\hline Washing & 100.0 & Water & 10 & Horse up - samming - dry hanging \\
\hline
\end{tabular}

Egyptian J. Desert Res., 68, No. 1, 75-88 (2018) 


\section{Statistical Analysis}

Data of physical and chemical properties of tanned leathers were analyzed using GLM procedure of SAS (2008) to evaluate the differences among produced leathers. The following model was used in the analysis:

$$
Y_{i j}=\mu+T_{i}+e_{i j}
$$

Where $Y_{i j}$ is the observation taken on finished leather, $\mu$ is overall mean, $T_{i}$ is a fixed effect of the $i^{\text {th }}$ tanning group $(1=\mathrm{G} 1,2=\mathrm{G} 2,3=\mathrm{G} 3,4=\mathrm{G} 4$ and $5=\mathrm{G} 5)$ and $\mathrm{e}_{\mathrm{ij}}$ is the random error assumed to be normally distributed with mean $=0$ and variance $=\sigma^{2} \mathrm{e}$.

\section{RESULTS AND DISCUSSION}

\section{Chrome Shaving Waste Characteristics}

The chemical properties of collected CSW were determined at the first stage of this study and their results are shown in table (2). The values of chemical characteristics were in agreement with previous literature (Sethuraman et al., 2013; Putshaka et al., 2015 and Abebaw and Abate, 2018). CSW is similar to ordinary chrome tanned leather in chemical characteristics. The reason is due to that CSW is mainly collagen fibers, which produced as a residue of shaving machine when adjusting leather thickness (BASF, 2007).

Regarding high protein content (TKN 12.66\%) and low fat content $(0.29 \%)$ of CSW, it is for removing flesh, fats and globular proteins from pelts in beam house, before tanning, to purify collagen fibers from other filling materials (Dutta, 2008).

On the other hand, determined total energy of CSW $(3515.33 \mathrm{cal} / \mathrm{g})$ is tended to be lower than those found by Muralidhara et al. (1982), Chattopadhyay et al. (2011) and Forero-Núñez et al. (2015). That might be due to the very low content of fat of CSW in this study.

Table (2). Characteristics chrome shaving waste.

\begin{tabular}{lccc}
\hline Parameter & ASTM & Value & Unit \\
\hline Moisture content & D-6403 & 10.24 & $\%$ \\
Ash content & D-2617 & 12.37 & $\%$ \\
Chromium content & D-6714 & 2.51 & $\%$ \\
Fat content & D-3495 & 0.29 & $\%$ \\
Total Kjeldahl Nitrogen (TKN) & D-2868 & 12.66 & $\%$ \\
pH value & D-2810 & 3.32 & $\mathrm{ml} \mathrm{mol} / \mathrm{L}$ \\
Total energy (dry) & D-5865 & 3515.33 & $\mathrm{cal} / \mathrm{g}$ \\
\hline
\end{tabular}




\section{Chrome Extraction Yield}

Fig. (4) shows the extraction yield of different chrome recovery treatments. The effect of sodium hydroxide and sodium carbonate in hydrolysis is due to the following reactions equations, respectively:

$$
\begin{aligned}
\mathrm{Cr}_{2}\left(\mathrm{SO}_{4}\right)_{3}+6 \mathrm{NaOH} & \rightarrow 2 \mathrm{Cr}(\mathrm{OH})_{3}+3 \mathrm{Na}_{2} \mathrm{SO}_{4} \\
\mathrm{Cr}_{2}\left(\mathrm{SO}_{4}\right)_{3}+3 \mathrm{Na}_{2} \mathrm{CO}_{3}+3 \mathrm{H}_{2} \mathrm{O} & \rightarrow 2 \mathrm{Cr}(\mathrm{OH})_{3}+3 \mathrm{Na}_{2} \mathrm{SO}_{4}+3 \mathrm{CO}_{2}
\end{aligned}
$$

As explained by Covington (2011), chromium (III) salts are stable in the range $\mathrm{pH} 2-4$, where the basicity changes, but at higher values they will precipitate. This can be modeled in the following way, using empirical formulae:

$$
\begin{gathered}
\mathrm{Cr}^{3+}+\mathrm{OH} \leftrightarrow[\mathrm{Cr}(\mathrm{OH})]^{2+}+\mathrm{OH}_{\mathrm{CH}}\left[\mathrm{Cr}(\mathrm{OH})_{2}\right]^{+}+\mathrm{OH} \leftrightarrow \mathrm{Cr}(\mathrm{OH})_{3} \\
\mathrm{Cr}(\mathrm{OH})_{3}+\mathrm{OH} \leftrightarrow \mathrm{CrO}_{2}^{-} \text {(Chromite salt) }+\mathrm{H}_{2} \mathrm{O}
\end{gathered}
$$

The chemical effect of sodium hydroxide on the recovery ratio (97.87\%) was more effective than sodium carbonate (91.92\%) at the same concentration $10 \%$. That means the greatest effect of caustic soda in alkaline hydrolysis due to the change in $\mathrm{pH}$ value (Mohamed et al., 2013 and Sutyasmi and Supraptiningsih, 2014).

In incineration method because of the high operating temperatures, the residue from incineration is mainly ash. The ash contains chromium trioxide $\left(\mathrm{Cr}_{2} \mathrm{O}_{3}\right)$, which is a very stable compound. Therefore, the extraction method by incineration was the highest $(99.37 \%)$ and best extraction method compared with other alkaline hydrolysis methods.

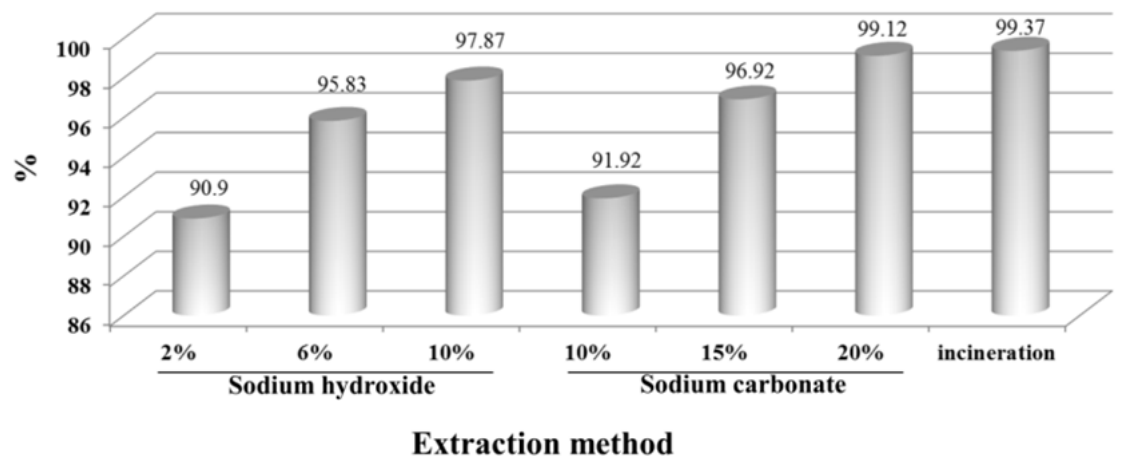

Fig. (4). Extraction yields of different extracted chrome shaving waste.

\section{Maximization Chrome Extraction Yield of Incineration Method}

Maximization of extraction yield was done in the second stage of this work by applying incineration under different levels of pH. Fig. (5) shows extraction yield and chrome basicity values of recovered chromium by incineration. The highest extraction yield was found when using sugar as reducing agent $(99.65 \%)$, while using sodium sulphite at three levels of $\mathrm{pH}$ gave close values of yields. 
Covington (2011) explained that chrometrioxide $\left(\mathrm{Cr}_{2} \mathrm{O}_{3}\right)$ produces after incineration and converts into sodium dichromate $\left(\mathrm{Na}_{2} \mathrm{Cr}_{2} \mathrm{O}_{7}\right)$, which becomes a chrome tanning liquor, when treats with sugar or sodium sulphite. Sodium dichromate is fused with a base, typically sodium carbonate, at around $1000^{\circ} \mathrm{C}$ in the presence of air:

$$
2 \mathrm{Cr}_{2} \mathrm{O}_{3}+4 \mathrm{Na}_{2} \mathrm{CO}_{3}+3 \mathrm{O}_{2} \rightarrow 4 \mathrm{Na}_{2} \mathrm{CrO}_{4}+4 \mathrm{CO}_{2}
$$

This step solubilizes the chromium and allows it to be extracted into hot water. Acidification of the resulting aqueous extract with sulfuric acid or carbon dioxide affords the dichromate:

$$
2 \mathrm{Na}_{2} \mathrm{CrO}_{4}+2 \mathrm{CO}_{2}+\mathrm{H}_{2} \mathrm{O} \rightarrow \mathrm{Na}_{2} \mathrm{Cr}_{2} \mathrm{O}_{7}+2 \mathrm{NaHCO}_{3}
$$

The treatment with sodium sulphite is producing chromium sulphate in one step as described in the next equation:

$$
\mathrm{Na}_{2} \mathrm{Cr}_{2} \mathrm{O}_{7}+3 \mathrm{Na}_{2} \mathrm{SO}_{3}+4 \mathrm{H}_{2} \mathrm{SO}_{4} \rightarrow \mathrm{Cr}_{2}\left(\mathrm{SO}_{4}\right)_{3}+4 \mathrm{Na}_{2} \mathrm{SO}_{4}+4 \mathrm{H}_{2} \mathrm{O}
$$

While using sugar as a reduction agent is producing chromium sulphate in two consecutive chemical reactions as follows:

$$
\begin{gathered}
4 \mathrm{Na}_{2} \mathrm{Cr}_{2} \mathrm{O}_{7}+12 \mathrm{H}_{2} \mathrm{SO}_{4}+\mathrm{C}_{6} \mathrm{H}_{12} \mathrm{O}_{6} \rightarrow \\
8 \mathrm{Cr}(\mathrm{OH}) \mathrm{SO}_{4}+4 \mathrm{Na}_{2} \mathrm{SO}_{4}+6 \mathrm{CO}_{2}+14 \mathrm{H}_{2} \mathrm{O} \\
2 \mathrm{Cr}(\mathrm{OH}) \mathrm{SO}_{4}+\mathrm{H}_{2} \mathrm{SO}_{4} \rightarrow \mathrm{Cr}_{2}\left(\mathrm{SO}_{4}\right)_{3}+2 \mathrm{H}_{2} \mathrm{O}
\end{gathered}
$$

Therefore, when using sodium sulphite as a reducing agent, the basicity of produced chromium sulphate affected by the change in $\mathrm{pH}$ level. However, that is not done when using sugar, which produced chromium sulphate with $33 \%$ basicity. It is more common to be used in tanneries since it is more suitable to be cross linked with collagen fibers (Covington, 2011).

From the results of basicity and extraction yield, producing tanning liquor from CSW by incineration and acidification using sulphuric acid and sugar is considered the optimum method.

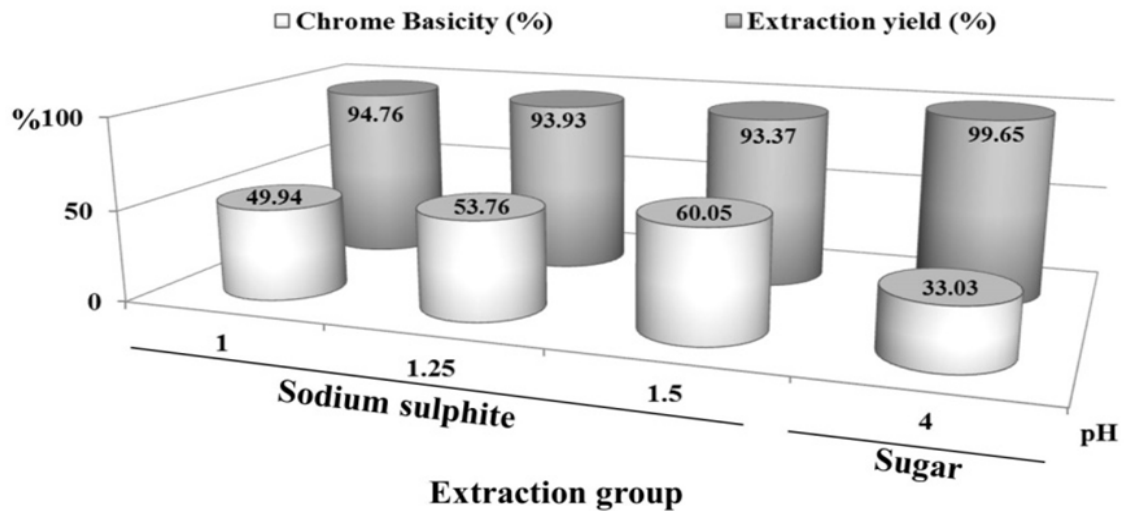

Fig. (5). Extraction yield and chrome basicity of recovered chromium by incineration. 


\section{Properties of Chrome Tanned Leathers}

The physical and chemical properties of tanned leathers with different levels of prepared chromium shulphate were presented in tables (3) and (4), respectively. All values of physical and chemical properties were in acceptable range of commonly chrome tanned leathers, which means the similarity among all tanned groups and possibility of using them in different manufacturing purposes (BASF, 2007). Although the values of physical and chemical properties are in narrow ranges, tensile strength, ash content and fat content values showed significant differences. Tensile strength had significantly $(P<0.01)$ the highest value $\left(203.62 \mathrm{~kg} / \mathrm{cm}^{2}\right)$ in tanned leathers with $50 \%$ of commercial chrome and $50 \%$ of recovered chrome. The values of ash and fat contents tended to increase by increasing addition of recovered chrome. Thus, tanned leathers with $100 \%$ of recovered chrome were the highest in ash content (6.60\%) and fat content (10.13\%). Dutta (2008) and Covington (2011) illustrated that in fat liquoring of chrome tanned leathers, the negatively charged $\left(-\mathrm{OSO}_{3}{ }^{-}\right)$ions penetrate into the chrome complex and therefore act as masking agents, which improve the crosslink among collagen fibers and fat liquor. It appeared that addition of recovered chrome may increase collagen fibers activity to be more covered with fat liquor, which increased fat content and thus ash content.

Table (3). Physical properties of tanned leathers with different additions of recovered chromium salts.

\begin{tabular}{|c|c|c|c|c|c|c|c|c|}
\hline \multirow{2}{*}{\multicolumn{2}{|c|}{ Property }} & \multirow[t]{2}{*}{ Thickness } & \multicolumn{2}{|c|}{ Strengths } & \multirow[t]{2}{*}{ Elongation } & \multicolumn{2}{|c|}{$\begin{array}{c}\text { Water } \\
\text { absorption }\end{array}$} & \multirow[t]{2}{*}{ PWV } \\
\hline & & & Tensile & Tear & & $2 \mathrm{~h}$ & $24 \mathrm{~h}$ & \\
\hline \multicolumn{2}{|c|}{ Unit } & $\mathbf{m m}$ & $\mathrm{kg} / \mathrm{cm}^{2}$ & $\mathrm{~kg} / \mathrm{cm}$ & $\%$ & $\%$ & $\%$ & $\mathrm{mg} / \mathrm{mm}^{2} / \mathrm{h}$ \\
\hline \multicolumn{2}{|c|}{ ASTM } & D1813 & D2209 & D4704 & D2211 & D6015 & D6015 & D5052 \\
\hline \multirow{5}{*}{$\begin{array}{l}\text { Recovered } \\
\text { chrome } \\
\text { addition }\end{array}$} & $0 \%$ & 0.91 & $158.82^{\mathrm{b}}$ & 36.41 & 59.01 & 214.12 & 228.05 & 5.48 \\
\hline & $25 \%$ & 0.91 & $201.91^{\mathrm{a}}$ & 40.80 & 55.43 & 194.46 & 209.73 & 5.80 \\
\hline & $50 \%$ & 0.89 & $203.62^{\mathrm{a}}$ & 38.51 & 57.82 & 192.43 & 199.96 & 5.40 \\
\hline & $75 \%$ & 0.91 & $156.76^{\mathrm{b}}$ & 34.46 & 58.10 & 185.35 & 197.11 & 5.56 \\
\hline & $100 \%$ & 0.90 & $184.99^{\mathrm{ab}}$ & 35.02 & 63.35 & 212.51 & 226.30 & 5.74 \\
\hline \multicolumn{2}{|c|}{ SEM } & 0.01 & 6.09 & 0.95 & 1.39 & 6.19 & 6.46 & 0.08 \\
\hline \multicolumn{2}{|c|}{ Significance } & NS & $* *$ & NS & NS & NS & NS & NS \\
\hline
\end{tabular}

Means in the same column having different superscripts are significantly different $(P<0.05)$.

ASTM: determination method according to American Society for Testing and Materials.

PWV: permeability to water vapor.

SEM: standard error of the mean.

NS: not significant, $* * P<0.01$ 
Table (4). Chemical properties of tanned leathers with different additions of recovered chromium salts.

\begin{tabular}{c|cccccc}
\hline \multicolumn{2}{c}{ Property } & $\mathbf{p H}$ & Moisture & Fat & Ash & Cr \\
\hline Unit & $\mathbf{m l ~ m o l} / \mathbf{L}$ & $\mathbf{\%}$ & $\mathbf{\%}$ & $\mathbf{\%}$ & $\mathbf{\%}$ \\
\multicolumn{2}{c}{ ASTM } & $\mathbf{D 2 8 1 0}$ & $\mathbf{D 6 4 0 3}$ & $\mathbf{D 3 4 9 5}$ & $\mathbf{D 2 6 1 7}$ & $\mathbf{D 6 7 1 4}$ \\
& $\mathbf{0 \%}$ & 3.73 & 15.66 & $7.33^{\mathrm{b}}$ & $5.77^{\mathrm{c}}$ & 3.02 \\
Recovered & $\mathbf{2 5 \%}$ & 3.67 & 15.19 & $8.95^{\mathrm{ab}}$ & $5.45^{\mathrm{c}}$ & 3.31 \\
chrome & $\mathbf{5 0 \%}$ & 3.85 & 15.53 & $10.39^{\mathrm{a}}$ & $6.15^{\mathrm{b}}$ & 3.91 \\
addition & $\mathbf{7 5 \%}$ & 3.68 & 15.45 & $9.96^{\mathrm{a}}$ & $6.24^{\mathrm{ab}}$ & 2.51 \\
& $\mathbf{1 0 0 \%}$ & 3.71 & 14.74 & $10.13^{\mathrm{a}}$ & $6.60^{\mathrm{a}}$ & 2.77 \\
\multicolumn{2}{c}{ SEM } & 0.02 & 0.12 & 0.36 & 0.10 & 0.17 \\
\multicolumn{2}{c}{ Significance } & $\mathrm{NS}$ & $\mathrm{NS}$ & $*$ & $* *$ & $\mathrm{NS}$ \\
\hline
\end{tabular}

Means in the same column having different superscripts are significantly different $(P<0.05)$. ASTM: determination method according to American Society for Testing and Materials SEM: standard error of the mean

NS: not significant, ${ }^{*} P<0.05,{ }^{* *} P<0.01$

\section{CONCLUSION}

The results of the current study pointed out the efficiency of extracting chromium salts from chrome shaving wastes and converting it into tanning liquor in order to achieve some environmental and economic benefits. Incineration of chrome shaving wastes is considered as an easy method to obtain high yield of chromium salts and convert it into chrome sulphate (33\% basicity) by acidification with sulphuric acid, then add sugar as a reducing agent. Furthermore, it generates good thermal energy, which can be utilized in tannery to save energy cost. However, the rising fumes from incineration need further studies to avoid their negative impact on the environmental.

\section{ACKNOWLEDGMENT}

Authors would like to thank Mr. Mohamed Hamdy El-Shaar, the owner of El-Shaar tannery, Cairo, Egypt and Mr. Sherif Amer Sharawy, the owner of Lumbroso tannery, Cairo, Egypt for their help and support in the practical part of this study.

\section{REFERENCES}

Abebaw, G. and B. Abate (2018). Chrome tanned leather waste dechroming optimization for potential poultry feed additive source: a waste to resources approach feed for future. J. Environ. Pollut. Manag., 1 (1): $1-6$. 
Alves Dos Reis, M. and V. Beleza (1991). Utilization of leather waste: animal feed stuff from chrome shavings. J. Soc. Leather Technol. Chem., 75 (2): 45-47.

ASTM (2014). In "Books of Standards". Vol. 15.04. American Society for Testing and Materials, USA.

BASF (2007). In "Pocket Book for Leather Technologist". $4^{\text {th }}$ edition, 67056 Ludwigshafen, Badische Anilin- und Soda-Fabrik, Germany.

Beltrán-Prieto, J.C., R. Veloz-Rodríguez, M.C. Pérez-Pérez, J.L. NavarreteBolaños, E. Vázquez-Nava, H. Jiménez-Islas and J.E. Botello-Álvarez (2012). Chromium recovery from solid leather waste by chemical treatment and optimisation by response surface methodology. Chemistry and Ecology, 28 (1): 89-102.

Chattopadhyay, B., A.R. Goswami, A. Aich, S. Datta and S. Mukhopadhyay (2011). Characterization of tannery solid wastes based fertilizers and fish-food. The Journal of Solid Waste Technology and Management, 4 (7): 253-259.

Covington, A.D. (2011). In "Tanning Chemistry the Science of Leather". RSC Publishing, Cambrige, London.

Dutta, S.S. (2008). In "An Introduction to the Principles of Leather Manufacture". $4^{\text {th }}$ edition, Indian Leather Techno Association, India.

FAOSTAT (2014). Production-Crops data. World Food And Agriculture Organization, ROME.

Forero-Núñez, C.A., J.A. Méndez-Velásquez and F.E. Sierra-Vargas (2015). Energetic improvement of tanned leather solid wastes by thermal treatment. Ingeniería y Desarrollo. Universidad del Norte, 33(1): 1-17.

Kantarli, I.C. and J. Yanik (2010). Activated carbon from leather shaving wastes and its application in removal of toxic materials. Journal of Hazardous Materials, 179: 348-356.

Lakrafli, H., S. Tahiri, A. Albizane and M.E.E. Otmani (2012). Effect of wet blue chrome shaving and buffing dust of leather industry on the thermal conductivity of cement and plaster based materials. Construction and Building Materials, 30: 590-596.

Mohamed, O.A., G.M. Taha and N.H. El-Sayed (2013). Technical gelatine from chrome tanned shavings. Int. J. Environment and Waste Management, 11 (4): 335-349.

Muralidhara, H.S., B. Maggin and H.J. Phipps (1982). Conversion of tannery waste to useful products. Resources and Conservation, 8: 43-59.

Putshaka, D.J., A. Yakubu, A. Jauro, M. Harami and M. Kolo (2015). Effect of alkali and acid concentration in extraction of chromium III from tannery solid waste. American Journal of Chemistry and Application, 2 (6): 89-94.

Salma, A.A., A.G. Gurashi and A.E. Musa (2013). Extraction of chromium six from chrome shavings. Journal of Forest Products and Industries, 2 (2): 21-26.

Egyptian J. Desert Res., 68, No. 1, 75-88 (2018) 
Sanjuán-Herráez, D., L. Chabaane, S. Tahiri, A. Pastor and M. Guardia (2012). Preliminary results on the use of leather chrome shavings for air passive sampling. Journal of Analytical Methods in Chemistry, 2012: 1-6.

SAS (2008). In "SAS/STAT 9.2 User's Guide". $2^{\text {nd }}$ edition, SAS Institute Inc., Cary, NC.

Sethuraman, C., K. Srinivas and G. Sekaran (2013). Double pyrolysis of chrome tanned leather solid waste for safe disposal and products recovery. Int. J. Sci. Eng. Res., 4 (11): 61-67.

Sutyasmi, S. and Supraptiningsih (2014). Chrome utilization of shaving waste for leather tanning. Majalah Kulit, Karet, Dan Plastik, 30 (2): 87-94. 


\section{معالجة مخلف سلاتة الكروم لتقليل أثره البيئي}

محمد جابر عبد الفضيل طه'، أحمد إبراهيم نصر مرسي ب*، حمدي السيد علي'، محمود

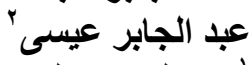

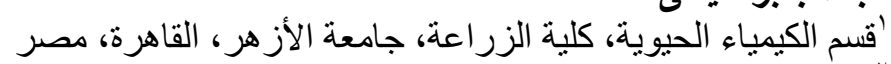

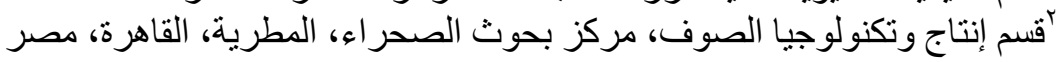

يعد مخلف سلاتة الكروم هو أحد أكبر مخلفات دباغة الجلود، والذي يسبب خسارة بيئية

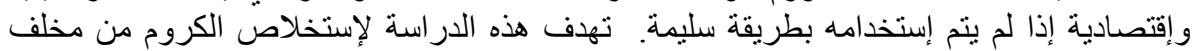

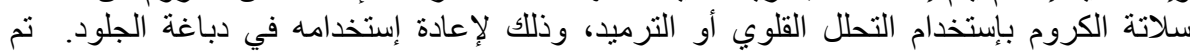

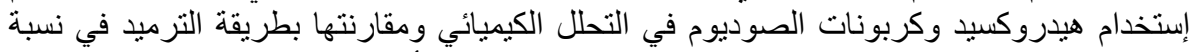

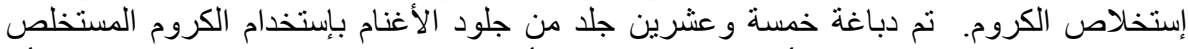

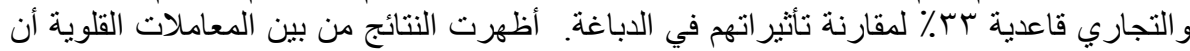

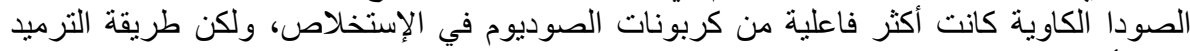

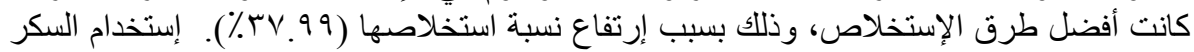

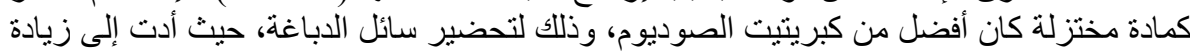

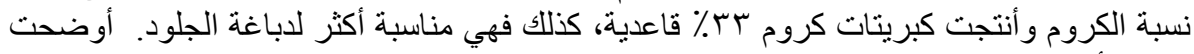

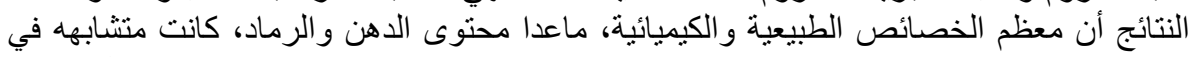

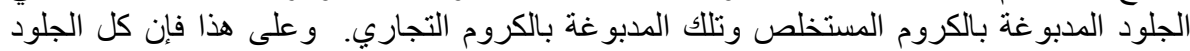

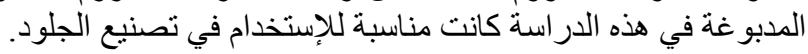

Egyptian J. Desert Res., 68, No. 1, 75-88 (2018) 